\title{
Intradural Schwannoma Exacerbating the Symptoms of Degenerative Lumbar Stenosis: Case Report
}

\section{Schwannoma intradural exacerbando sintomas de estenose lombar degenerativa: relato de caso}

\author{
Lucas Crociati Meguins ${ }^{1}$ Raphael dos Santos Abílio ${ }^{1}$ Herbert Cunha Moreira Santos ${ }^{1}$ \\ Linoel Curado Valsechi ${ }^{1} \quad$ Elísio Eduardo Cardoso Duarte ${ }^{1}$ Dionei Freitas de Morais ${ }^{1}$
}

${ }^{1}$ Hospital de Base, São José do Rio Preto, São Paulo Brazil

Arq Bras Neurocir 2017;36:38-42.
Address for correspondence Lucas Crociati Meguins, MD, MSc, Rua Pedro Palotta, 101/35B, Jardim Maracanã, São José do Rio Preto, SP, Brazil. 15092-205 (e-mail: lucascrociati@hotmail.com).

\section{Abstract \\ Keywords \\ - intradural schwannoma \\ - lumbar disc herniation \\ - spinal stenosis}

\section{Resumo}

Introduction Schwannoma is a common intradural slow-growing, benign and encapsulated tumor that originates from the myelin sheaths of the nerve fibers. However, a lumbar schwannoma complicating the symptoms of spinal stenosis is an extremely rare association.

Aim To describe the case of a woman presenting a lumbar schwannoma in association with spinal stenosis.

Case Report A 53 year-old female was referred to neurosurgical evaluation due to the worsening of a lumbar pain that was irradiating to the left inferior leg along the anterolateral surface. A neurological examination revealed motor deficits for extension of the left leg and attenuation of the left patellar reflex. Magnetic resonance imaging (MRI) showed lumbar spinal stenosis due to flavum ligament hypertrophy and disc herniation in the L3L4 and L4L5 segments, and an expansive lesion with homogeneous contrast enhancement occupying the left neuroforamen of the L3L4 segment. The patient underwent surgical resection of the tumor and decompression of the stenotic segments with posterior screw instrumentation from L3 to L5. She presented an uneventful recovery and significant improvement of the lumbar pain, and was still free of symptoms 6 months after surgery. An anatomopathological examination defined the tumor as a schwannoma (Grade I - World Health Organization [WHO]).

Conclusion The present study highlights that lumbar schwannoma is a possible etiology complicating the symptoms of patients with previous lumbar spinal stenosis. It is important to treat both pathologies to improve the patients' symptoms.

Introdução O schwannoma é um tumor intradural comum, benigno, de crescimento lento e encapsulado que se origina da bainha de myelina das fibras nervosas. No received

September 5, 2016 accepted

November 24, 2016

published online

January 7, 2017
DOI http://dx.doi.org/

$10.1055 / \mathrm{s}-0036-1597772$ ISSN $0103-5355$.
Copyright @ 2017 by Thieme Revinter

Publicações Ltda, Rio de Janeiro, Brazil
License terms

(c) $(1) \$$ 
entanto, a presença de um schwannoma lombar complicando os sintomas de estenose do canal medular é uma associação extremamente rara.

Objetivos Descrever o caso de uma paciente portadora de schwannoma lombar exacerbando os sintomas de estenose do canal lombar.

Relato de Caso Uma mulher de 53 anos de idade foi encaminhada para avaliação neurocirúrgica devido a relato de piora dos sintomas de dor lombar que irradiavam preferencialmente para o membro inferior esquerdo na sua face antero-lateral. 0 exame físico neurológico revelou a presença de déficit motor para a extensão do membro inferior esquerdo e redução do reflexo patelar esquerdo. A imagem de ressonância magnética mostrou a presença de estenose do canal lombar devido à hipertrofia do ligamento amarelo e herniações discais nos segmentos L3L4 e L4L5. Além disso, o estudo radiológico também evidenciou a presença de uma lesão expansiva ocupando o neuroforamen de L3L4 com captação homogênea do meio de contraste. A paciente foi submetida à ressecção cirúrgica do processo neoplásico e descompressão do canal medular com artrodese através de instrumentação dos segmentos $L 3 L 4 L 5$ via posterior em um único ato operatório. A paciente apresentou uma recuperação pós-operatória adequada e mantém-se assintomática em segmento

\section{Palavras-chave}

- schwannoma intradural

- herniação discal lombar

- estenose de canal medular clínico seis meses após o procedimento cirúrgico. O estudo anatomo-patológico e imuno-histoquímico definiu o processo expansivo como schwannoma (Grau I da OMS). Conclusão O presente estudo destaca que o schwannoma lombar é uma possibilidade etiológica para os pacientes portadores de estenose do canal lombar que apresentam piora progressiva dos sintomas ou novos déficits neurológicos. É importante tratar as duas patologias para que o paciente obtenha melhor resultado clínico no controle dos sintomas.

\section{Introduction}

Spinal schwannomas are slow-growing tumors that account for one-fifth of all spinal tumors. Their presentation is usually insidious, and most patients complain of extreme pain. ${ }^{1-3}$ However, a spinal schwannoma complicating the symptoms of lumbar canal stenosis is an extremely rare association. ${ }^{4-9}$ The aim of the present study is to describe the case of a woman presenting a lumbar schwannoma in association with spinal stenosis.

\section{Case Report}

A 62 year-old woman was referred to neurosurgical evaluation due to the worsening of a lumbar pain that was irradiating to the left inferior leg along the anterolateral surface. A neurological examination revealed motor deficits for extension of the left leg and attenuation of the left patellar reflex. Magnetic resonance imaging (MRI) showed lumbar spinal stenosis due to flavum ligament hypertrophy and disc herniation in the L3L4 and L4L5 segments, and an expansive lesion with homogeneous contrast-enhancement occupying the left neuroforamen of the L3L4 segment ( - Fig. 1A, B, C). The patient underwent surgical resection of the tumor (-Fig. 1D) and decompression of the stenotic segments with posterior screw instrumentation from L3 to L5. As long as the tumor was only affecting the posterior root, the motor segment of the nerve root was preserved. She presented an uneventful recovery and significant improvement of the lumbar pain, and was still free of symptoms 6 months after surgery. An anatomopathological examination defined the tumor as a schwannoma (Grade I - World Health Organization [WHO]) (-Figs. 2 and $\mathbf{3}$ ).

\section{Discussion}

Spinal schwannomas account for $\sim 25 \%$ of the primary intradural spinal cord tumors in adults. Their presentation is usually insidious, and most patients complain of extreme pain. ${ }^{1-3}$ It is a benign nerve sheath neoplasm with its vast majority located at the intradural space, and occasionally presenting as an extradural or a dumbbell-shaped lesion. ${ }^{10-12}$ Intradural schwannomas may produce signs and symptoms similar to those of disc herniation, such as back pain and neurological deficits. ${ }^{12-14}$ Magnetic resonance imaging (MRI) usually reveals a well-delineated contrastenhancing, encapsulated and isolated mass, with a hypointense or isointense sign on the T1 weighted images, and a hyperintense sign on the T2 weighted images. ${ }^{10,15,16}$ On the other hand, posterior or postero-lateral epidural migration of a herniated lumbar disc fragment presents signs similar to those of a disc on both T1 and T2-weighted MR sagittal images. ${ }^{17-19}$ Additionally, a disc fragment may also show peripheral contrast-enhancement and rarely mimic an intradural spinal tumor. ${ }^{20,21}$ Occasionally, a histological study is the only way to verify the diagnosis. 


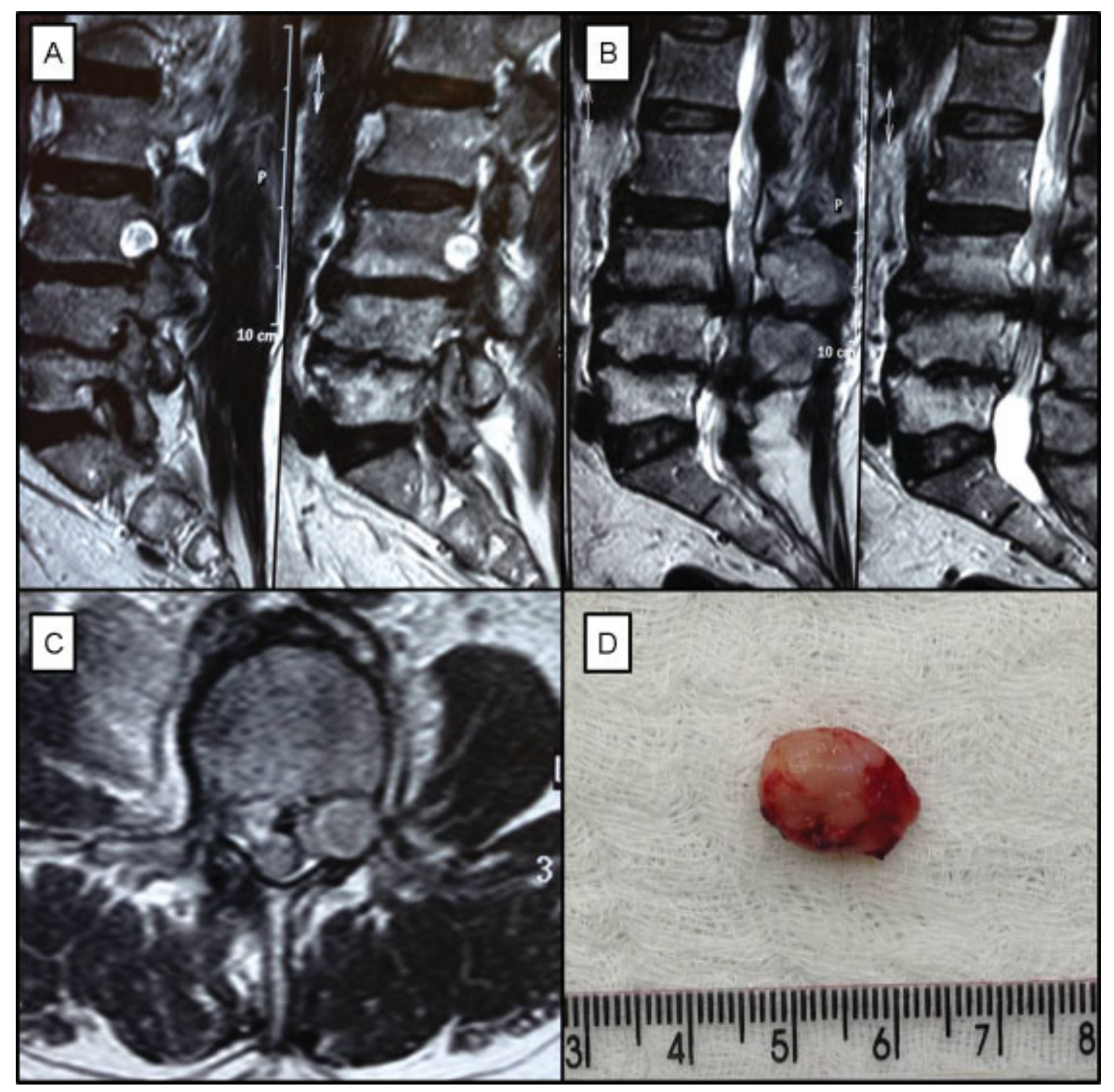

Fig. 1 Magnetic resonance imaging of the lumbar spine $(A / B / C)$ and intradural schwannoma after resection (D).

However, a spinal schwannoma complicating the symptoms of lumbar canal stenosis due to disc herniation is an extremely rare association, with only few reported cases. In - Table 1, we show a summary of similar published reports in the literature in English presenting intervertebral lumbar disc herniation coexisting with an intradural tumor. ${ }^{5-9}$ Albert and colleagues, in $1988,{ }^{5}$ described the case of a 52 year-old male patient suffering from lumbar pain from a $\mathrm{L} 4$ / L5 disc herniation together with a neurinoma at the L 5 nerve root. Liu and colleagues, in 2007, ${ }^{6}$ reported the case of a 51 year-old man presenting cauda equine syndrome resulting from a L2/L3 disc herniation coexisting with a lumbar schwannoma. Bathia and colleagues, in $2013,{ }^{7}$ described the case of a 33 year-old man with a clinical presentation of left sciatica associated with paresthesia in the left $\mathrm{S} 1$ dermatome due to a L5/S1 disc herniation in association with a paraganglioma. Baek and colleagues, in 2014, ${ }^{8}$ reported a case of an intradural schwannoma coexisting with lumbar disc herniation at the L4/L5 disc level in a 71 year-old woman suffering from lower back pain and L5 radiculopathy. Pan and colleagues, in 2016, ${ }^{9}$ described another case of a lumbar schwannoma coexisting with a L3/L4 disc herniation in a 67 year-old man presenting with low back pain and right leg radiculopathy resulting from $\mathrm{L} 4$ nerve root compression. In all previously reported cases, intradural tumor resection and discectomy were performed through posterior approach..$^{5-9}$ In our case, a 62 year-old woman was treated surgically by intradural tumor resection and discectomy through

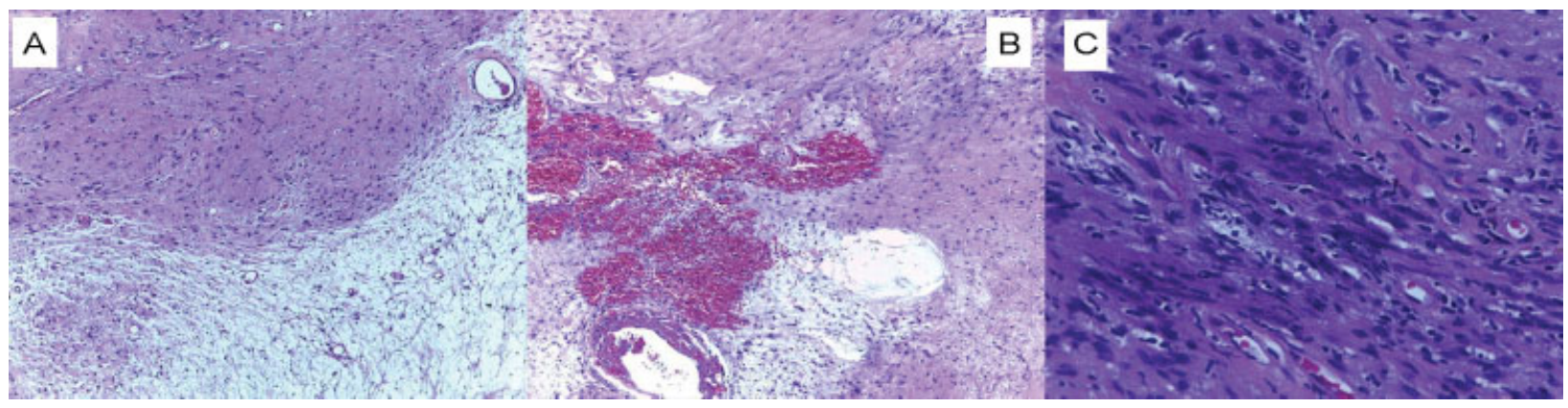

Fig. 2 Anatomopathological aspect of the tumor (hematoxylin and eosin). 


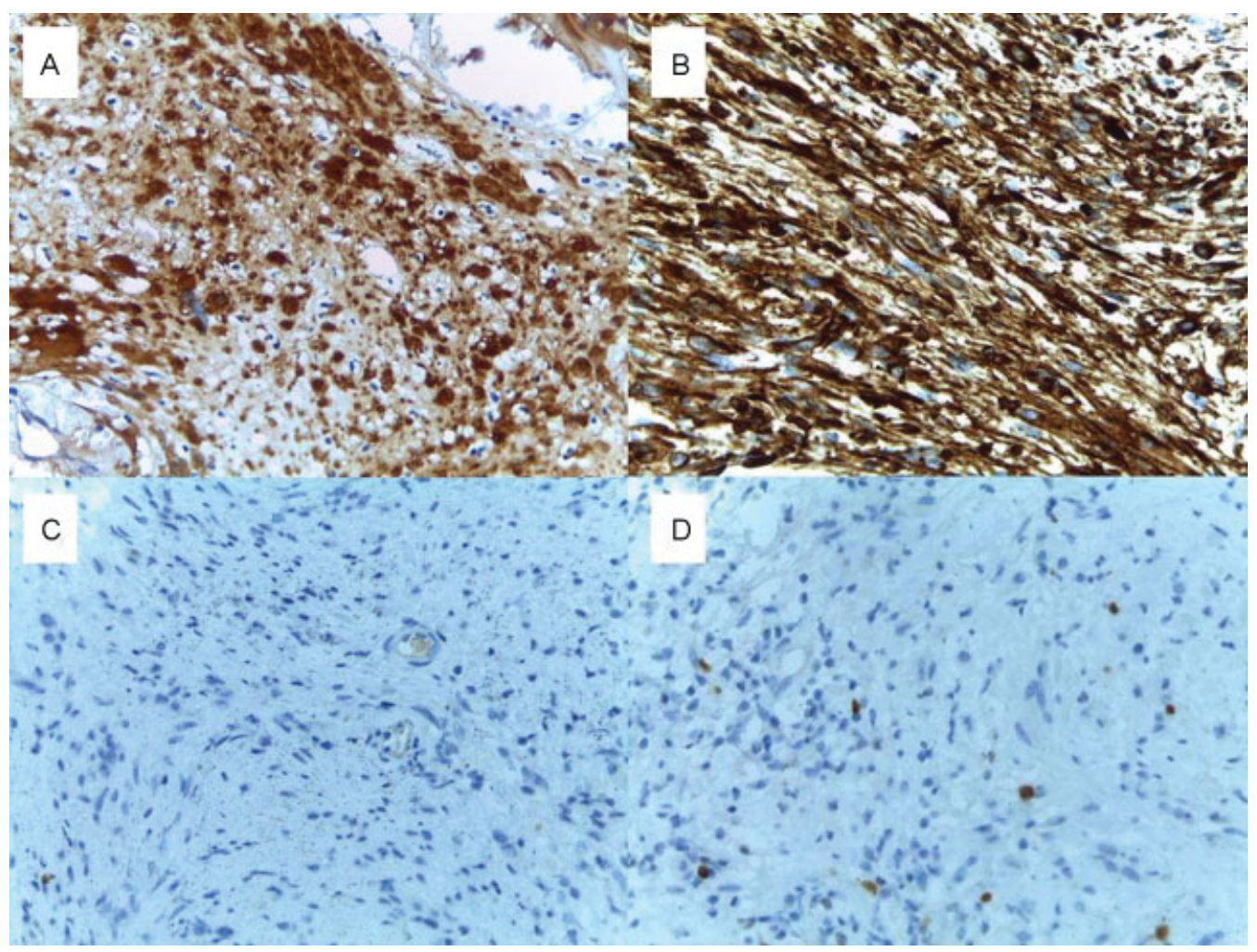

Fig. 3 Immunohistochemistry study of the tumor (A: S-100 protein positive/B: Vimentin positive/C: Epithelial membrane antigen [EMA] negative/D: $\mathrm{K}_{\mathrm{i}}-67$ positive [2\%]).

Table 1 Summary of cases with intradural schwannoma and lumbar disc herniation

\begin{tabular}{|c|c|c|c|c|c|}
\hline Authors/Year & Age & Gender & Symptoms & Sgt* & Treatment \\
\hline Albert et al/1988 ${ }^{5}$ & 52 & M & Lumbar back pain & L4/L5 & tumor resection/discectomy \\
\hline Liu et al/2007 ${ }^{6}$ & 51 & M & Cauda equine syndrome & L2/L3 & tumor resection/discectomy \\
\hline Bhatia et al/2013 ${ }^{7}$ & 33 & M & Sciatic pain and paresthesia & L5/S1 & tumor resection/discectomy \\
\hline Baek et al/2014 ${ }^{8}$ & 71 & $\mathrm{~F}$ & Lumbar back pain & L4/L5 & tumor resection/discectomy \\
\hline Pan et al/2016 ${ }^{9}$ & 67 & M & Lumbalgy and sciatalgy & $\mathrm{L} 3 / \mathrm{L} 4$ & tumor resection/discectomy \\
\hline Current study & 62 & $\mathrm{~F}$ & Sciatic pain and motor deficit & $\mathrm{L} 3 / \mathrm{L} 4$ & tumor resection/discectomy \\
\hline
\end{tabular}

Abbreviations: F, female; M, male; Sgt*, lumbar spine segment affected.

posterior laminectomy and pedicular instrumentation. To our knowledge, the present case is the sixth case reported so far in the literature in English. ${ }^{5-9}$

Low back pain, radiculopathy or cauda equine syndrome are all symptoms identified in patients suffering from spinal stenosis, lumbar disc herniation or an intradural tumor compressing neural structures, such as the nerve roots, the conus medullaris or the spinal cord. ${ }^{22-24}$ Acute or chronic presentations have also been reported, and they make the diagnosis possible when a specific dermatome is referred by the patient. However, when clinical symptoms cannot be fully explained by an identified disease, the coexistence of another spinal pathology should be considered. Magnetic Resonance study findings may help in stablishing the correct diagnosis. ${ }^{5-9}$
In conclusion, the present case highlights that the coexistence of an intradural schwannoma and lumbar disc herniation may be present in patients referring clinical deterioration of low back pain and radiculopathy. We reinforce that complete history, a careful physical examination, and investigative measures, such as the MRI, are usually necessary to stablish the correct diagnosis and the most appropriate surgical treatment. It is important to treat both pathologies to improve the patients' symptoms.

\section{References}

1 Safaee MM, Lyon R, Barbaro NM, et al. Neurological outcomes and surgical complications in 221 spinal nerve sheath tumors. J Neurosurg Spine 2016;2016:1-9 
2 Godlewski B, Klauz G, Czepko R. Thoracic Nerve Root Schwannoma Filling the Spinal Canal Almost Entirely Without any Neurological Deficits. Anesth Pain Med 2016;6(1):e33886

3 Ando K, Imagama S, Ito Z, et al. How do spinal schwannomas progress? The natural progression of spinal schwannomas on MRI. J Neurosurg Spine 2016;24(1):155-159

4 Monteiro P, Garcia J, Salvador MJ, Malcata A. [Sacral schwannoma in a lumbar spinal stenosis: a rare condition]. Acta Reumatol Port 2009;34(2B):438-440

5 Albert FK, Oldenkott P, Bieker G, Danz B. Lumbar intervertebral disk herniation with a concomitant nerve root neurinoma at the same site. Case report and review of the literature. Neurochirurgia (Stuttg) 1988;31(6):222-225

6 Liu SY, Lin YM, Wei TS, Lin SJ, Liu CC, Chou CW. Exacerbation of symptoms of lumbar disc herniation complicated by a schwannoma: a case report. Kaohsiung J Med Sci 2007;23(9):480-485

7 Bhatia R, Jaunmuktane Z, Zrinzo A, Zrinzo L. Caught between a disc and a tumour: lumbar radiculopathy secondary to disc herniation and filum paraganglioma. Acta Neurochir (Wien) 2013;155(2): 315-317

8 Baek SW, Kim C, Chang H. Intradural schwannoma complicated by lumbar disc herniation at the same level: A case report and review of the literature. Oncol Lett 2014;8(2):936-938

9 Pan J, Wang Y, Huang Y. Coexistence of intervertebral disc herniation with intradural schwannoma in a lumbar segment: a case report. World J Surg Oncol 2016;14:113

10 Merhemic Z, Stosic-Opincal T, Thurnher MM. Neuroimaging of Spinal Tumors. Magn Reson Imaging Clin N Am 2016;24(3):563-579

11 Netra R, Hui MS, Gang MZ, Ming Z. Spinal cystic schwannoma: an MRI evaluation. J Coll Physicians Surg Pak 2014;24(2):145-147

12 Hirano K, Imagama S, Sato K, et al. Primary spinal cord tumors: review of 678 surgically treated patients in Japan. A multicenter study. Eur Spine J 2012;21(10):2019-2026

13 Chamberlain MC, Tredway TL. Adult primary intradural spinal cord tumors: a review. Curr Neurol Neurosci Rep 2011;11(3): $320-328$
14 Katonis P, Kontakis G, Pasku D, Tzermiadianos M, Tzanakakis G, Hadjipavlou A. Intradural tumours of the lumbar spine presenting with low back pain: report of two cases and review of the literature. Acta Orthop Belg 2008;74(2):282-288

15 Colosimo C, Cerase A, Denaro L, Maira G, Greco R. Magnetic resonance imaging of intramedullary spinal cord schwannomas. Report of two cases and review of the literature. J Neurosurg 2003; 99(1, Suppl)114-117

16 Ando K, Imagama S, Ito Z, et al. Differentiation of spinal schwannomas and myxopapillary ependymomas: MR imaging and pathologic features. J Spinal Disord Tech 2014;27(2):105-110

17 Majeed SA, Seshadrinath NA, Binoy KR, Raji L. Lumbar disc herniation: Is there an association between histological and magnetic resonance imaging findings? Indian J Orthop 2016; 50(3):234-242

18 Hong J, Ball PA. Images in clinical medicine. Resolution of Lumbar Disk Herniation without Surgery. N Engl J Med 2016;374(16): 1564

19 Karki DB, Adhikary KP, Gurung G. Magnetic Resonance Imaging Findings in Lumbar Disc Degeneration in Symptomatic Patients. J Nepal Health Res Counc 2015;13(30):154-159

20 Ekşi MS, Yener U, Akakin A, Akakin D, Konya D. Posterior epidural disc herniation at L3-L4 mimicking a spinal tumor: a case report. J Neurosurg Sci 2010;54(2):71-76

21 Toktaş ZO, Yılmaz B, Konya D, Yapıcıer O, Demir MK. Posterior epidural migration of lumbar disc fragment as an unusual ringenhancing mass. Spine J 2016;16(2):e31-e32

22 Yuan S, Zou Y, Li Y, Chen M, Yue Y. A clinically relevant MRI grading system for lumbar central canal stenosis. Clin Imaging 2016; 40(6):1140-1145

23 Selkirk SM, Ruff R. Low back pain, radiculopathy. Handb Clin Neurol 2016;136:1027-1033

24 Orita S, Yamashita T, Ohtori S, et al. Prevalence and Location of Neuropathic Pain in Lumbar Spinal Disorders: Analysis of 1804 Consecutive Patients With Primary Lower Back Pain. Spine 2016; 41(15):1224-1231 